\title{
Ancient out-of-Africa migration of Plasmodium falciparum along with modern humans
}

\author{
Kazuyuki Tanabe ${ }^{1 *}$, Toshihiro Mita ${ }^{2}$, Francois Balloux ${ }^{3}$ \\ From Parasite to Prevention: Advances in the understanding of malaria \\ Edinburgh, UK. 20-22 October 2010
}

Genetic diversity of Plasmodium falciparum is a key issue for better under $\hat{A} \neg$ standing of mortality, morbidity and effective control of malaria. However, little is known about the genetic makeup of $P$. falciparum populations.

It is generally assumed that the parasite population structure has been shaped by a variety of factors including transmission intensity, past intervention efforts and evolutionary history. Since P. falciparum is a parasite of man, its demographic history is expected to be intimately associated with that of modern humans. To assess the relative importance of human demographic history, we characterised spatial patterns of genetic diversity of $P$. falciparum populations by analyzing a worldwide sample of $>500$ isolates sequenced for two housekeeping genes (serca and adsl: 63 SNPs from 5.0 $\mathrm{kb}$ per isolate). We observed a strong negative correlation between within-population genetic diversity and geographic distance from Africa over Africa, Asia and Oceania, presenting evidence for isolation by distance pattern in P. falciparum. This negative correlation was also noted for two surface antigen genes ( $m s p 1$ and csp: 165 SNPs from $5.5 \mathrm{~kb}$ per isolate).

In contrast, regional variation in transmission intensity and recent control initiatives seem to have had a negligible impact on the distribution of genetic diversity, indicating that geography is the primary predictor of the genetic diversity of $P$. falciparum populations. The striking geographic patterns of isolation by distance mirror the ones previously documented in modern humans. Age estimates of $P$. falciparum populations, based on genetic distance between $P$. falciparum and $P$. reichenowi, a chimpanzee malaria parasite, strongly suggest that modern humans were infected prior to their exit

${ }^{1}$ Laboratory of Malariology, Research Institute for Microbial Diseases, Osaka University, Osaka 565-0871, Japan

Full list of author information is available at the end of the article
out-of-Africa and carried the parasite along during their colonization of the world.

\begin{abstract}
Author details
'Laboratory of Malariology, Research Institute for Microbial Diseases, Osaka University, Osaka 565-0871, Japan. ${ }^{2}$ Department of International Affairs and Tropical Medicine, Tokyo Women's Medical University, Tokyo 162-8666, Japan. ${ }^{3}$ MRC Centre for Outbreak Analysis and Modelling, Department of Infectious Disease Epidemiology, Faculty of Medicine, Imperia I College, London W2 1PG, UK.
\end{abstract}

Published: 20 October 2010

\section{Reference}

1. Kazuyuki Tanabe, Toshihiro Mita, Thibaut Jombart, Anders Eriksson, Shun Horibe, Nirianne Palacpac, Lisa Ranford-Cartwright, Hiromi Sawai, Naoko Sakihama, Hiroshi Ohmae, Masatoshi Nakamura, Marcelo UFerreira, Ananias AEscalante, Franck Prugnolle, Anders Björkman, Anna Färnert, Akira Kaneko, Toshihiro Horii, Andrea Manica, Hirohisa Kishino, Francois Balloux: Plasmodium falciparum accompanied the human expansion out of Africa. CurrBiol 2010, 20:1283-9.

doi:10.1186/1475-2875-9-S2-O30

Cite this article as: Tanabe et al:: Ancient out-of-Africa migration of Plasmodium falciparum along with modern humans. Malaria Journal 2010 9(Suppl 2):O30.

Submit your next manuscript to BioMed Central and take full advantage of:

- Convenient online submission

- Thorough peer review

- No space constraints or color figure charges

- Immediate publication on acceptance

- Inclusion in PubMed, CAS, Scopus and Google Scholar

- Research which is freely available for redistribution

Submit your manuscript at www.biomedcentral.com/submit

\section{Biomed Central}

(c) 2010 Tanabe et al; licensee BioMed Central Ltd. This is an open access article distributed under the terms of the Creative Commons Attribution License (http://creativecommons.org/licenses/by/2.0), which permits unrestricted use, distribution, and reproduction in any medium, provided the original work is properly cited. 